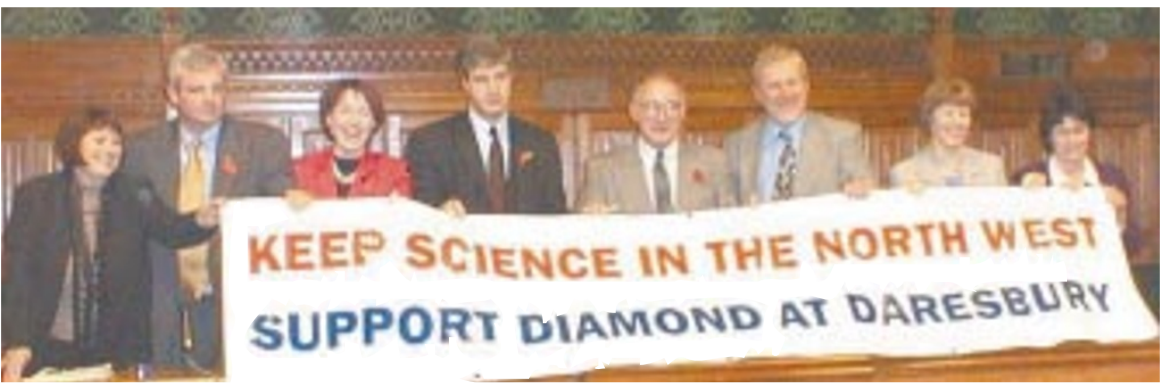

Out in force: local Members of Parliament show their support for siting Diamond at Daresbury.

\title{
Daresbury senses victory in battle for UK synchrotron
}

London

Speculation is mounting that Britain's nextgeneration synchrotron source, Diamond, will be located at Daresbury Laboratory outside Manchester. Scientists campaigning for Daresbury, rather than the rival Rutherford Appleton Laboratory (RAL) near Oxford, believe they have won their case. And French officials say that their British counterparts expressed a preference for Daresbury at a meeting last week.

Rumours over the siting of the $\mathfrak{E} 175$ million (US\$280 million) project intensified two weeks ago, after UK ministers met with the director-general of the Office of Science and Technology (OST) and the director of the Wellcome Trust.

Labour union officials at Daresbury say that Stephen Byers, the Secretary of State for Trade and Industry, has written to the trust saying the government is "minded" to site Diamond at Daresbury. The trust has also written to Daresbury's Member of Parliament (MP), Mike Hall, saying it has no strong views on where the source is sited.

Speculation on the decision has grown over the past three months (see Nature 401, 197; 1999). Local unions, MPs and scientists have campaigned to site Diamond at Daresbury, which houses the current UK Synchrotron Radiation Source, rather than at the RAL.

Last Thursday, senior officials from the OST, the Wellcome Trust and the French science ministry met in Paris to begin negotiations that will lead to a memorandum of understanding over the Anglo-French project. France has agreed in principle to contribute FF350 million (US\$56 million) towards the construction costs of Diamond over seven years, and FF60 million to FF80 million a year to its operating costs (see Nature 400, 489; 1999).

Michèle Leduc, an adviser at the ministry of research who attended the Paris meeting, said the British were likely to choose Daresbury - although a final decision awaits Byers' approval. “The British government has been under tremendous pressure to site the machine at Daresbury," says Leduc.

Although the French government had lobbied for the RAL, because of its proximity to Oxford, Leduc said that science minister Claude Allègre still intends to cooperate on the project. "For the French this does not represent a break-up," says Leduc. "It is still the minister's intention to cooperate with the project scientifically."

Last Friday and Monday of this week the Wellcome Trust sent representatives to both sites to assess the 'risks' associated with the project. Trust officials refuse to say what these might be, but said the visit was "to draw information" for a meeting of the trust's governors on Wednesday (10 November). Further news is expected after the meeting.

Although the trust says that the visit does not suggest that Diamond would necessarily be sited at Daresbury, campaigners feel it is significant. Susan Smith, a union representative and scientist at Daresbury, said it was the first time the trust had officially been to Daresbury since the siting of the facility became an issue.

Whatever is decided, it seems that the Central Laboratory for the Research Councils (CLRC), which manages both sites, may emerge with its reputation tarnished. Its refusal to state a site preference, says Tony Bell of the Institute of Professionals, Managers and Specialists - the union that represents many research council scientists - has "destroyed morale amongst staff". He adds that expertise from Daresbury will be needed to build the site wherever it is located.

It also seems likely that the CLRC will not have sole responsibility for managing the site; concerns that it is not working well are reflected in a critical report from the National Audit Office.

Last week, science minister Lord Sainsbury confirmed that the government was considering options for the management of the facility. "We are pulling in views," says Sainsbury. CLRC's perspective is "one of the views". Natasha Loder \& Heather McCabe
Cambridge, UK, hopes MIT magic will work on joint institute

Washington

The Massachusetts Institute of Technology (MIT) has agreed to found an institute at Britain's University of Cambridge, funded by the UK government, intended to nurture industrial innovation.

Both universities envisage a broadranging partnership which, they say, will set the pace for global alliances between other major universities.

The UK government will provide $\mathfrak{E} 68$ million (US\$110 million) over five years to launch the institute, which was announced in London on Monday by Gordon Brown, the UK Chancellor of the Exchequer. An additional $\mathfrak{\&} 16$ million from British industry will help the institute launch its first programmes.

These will include several MIT masters' courses in management and engineering at Cambridge. But the partnership is expected to expand to include exchange schemes for undergraduates and joint research in science and engineering, say senior officials at both universities.

Brown, who approached MIT after hearing that it was seeking a partnership with a European university, believes that the involvement of the famous US institution will help Britain address its long-standing difficulties in transferring technology from universities to industry.

"This is a path-breaking innovation," said Brown. "By choosing the United Kingdom as its European partner, MIT has recognized our country's strengths. The new institute will help us build on those by generating new ideas and by creating new business and jobs."

"We envisage a very broad engagement with Cambridge," says Larry Bacow, chancellor of MIT. "The intention is to stimulate innovation," he says, adding that this will involve basic research "in a number of areas, including neuroscience, biology, physics, materials and information technology".

UK politicians and industrialists have long envied the ability of top US research universities to stimulate innovation and economic growth. MIT is seen as the perfect model. A study estimated that its graduates have created corporations which would make up the twenty-fourth largest economy in the world (see Nature 386, 103; 1997).

Bacow says that this will be MIT's only "institute-wide, broad-based partnership" with a European university. Colin Macilwain 